(REviEW ARTiCLE)

\title{
Views on smoking free premise 2007, England; the gains so far
}

\author{
Lok Mani Giri ${ }^{1}$, Suyasha Koirala ${ }^{1}$ and Ahotovi Thomas Ahoto ${ }^{2, *}$ \\ ${ }^{1}$ Master of Science in Public Health (MScPH) The University of Southern Denmark (SDU), Esbjerg, Denmark \\ 2 School of Management Jiangsu University, 301 Xuefu Road, Zhenjiang, 212013, China
}

Magna Scientia Advanced Biology and Pharmacy, 2021, 02(01), 035-045

Publication history: Received on 06 March 2021; revised on 15 April 2021; accepted on 18 April 2021

Article DOI: https://doi.org/10.30574/msabp.2021.2.1.0014

\begin{abstract}
Smoking is one of the most avoidable cause of death and disability. Smoking not only affects smokers but also nonsmokers who are involuntarily exposed to smoke raising a serious concern for public health, safety, and welfare. Concerns regarding secondhand smoking came to the ground after various medical scientific researches and publications quantified and confirmed the health risk of passive smoking after exposure with it, which drew the public attention. The turning point for the government to introduce a ban of smoking at public and workplaces to protect the right of nonsmokers to enjoy fresh air, came as a 2006 Health Act in UK after it was strongly backed by the recommendation given by SCOTH regarding SHS. Through this policy, the government also supports internationally recognized comprehensive tobacco control standard. UK was first among the FCTC parties to introduce comprehensive smoke free legislation. The major objective of this policy is to limit the preventable epidemic of smoking.
\end{abstract}

This policy is based on the Health Policy Triangle which considers the interaction of all four elements (Content, Context, Process and Actors) to structure policymaking. For agenda setting Kingdon model was used and for implementation phase of the policy Top-down approach was used. The major stakeholders that supported 2006 Health Act were Labour party, The Royal College of physicians (RCP), Action on smoking and Health (ASH) and research and evidence-based news while Tobacco industry and hospital trade was against the Act. The evidence suggested that risks of heart disease in secondhand smoker was double than what was known before. SHS became an agenda when in 2003, around 11,000 adults exposed in home and 617 people exposed in workplace died in UK because of exposure to SHS. People want to quit smoking and wanted help from government to make favorable environment. Following the public consultation white paper was published, Choosing Health: Making Healthy Choices Easier, in November 2004. It set the target that by 2008 all enclosed public places and workplace would be smoke free with some exceptions. Act was supported by labour party and department of Health Economist was of the view that ban would not have any immediate benefits on passive smoker instead it will discourage the young from starting. After publishing the white paper in 2004 there was the consultation period till 2005. There was a voting in parliament and majority of voted for ban on smoking in public places. As a result, Health Act 2006 was introduced on $1^{\text {st }}$ July 2007. Smokers were against the ban, but the purpose of the ban was to focus on protecting health of people from SHS not make smokers quit. Reports disseminated after inspection from local bodies confirmed high levels of compliance with smoke free legislation. The data showed there were $2.4 \%$ reduction in hospital admission in a year for heart attack and almost 7000 fewer admission due to childhood asthma. Thus, Smoking ban policies have shown effective public health interventions for the prevention of cardiovascular, cerebrovascular, and respiratory mortality and preserve the health of children.

Keywords: Smoking; Policy; Stakeholder; United Kingdom;

\footnotetext{
${ }^{*}$ Corresponding author: Ahotovi Thomas Ahoto

School of Management Jiangsu University, 301 Xuefu Road, Zhenjiang, 212013, China.
} 


\section{Background and Aim of policy}

Smoking is the biggest avoidable cause of death and disability in developed countries and has created trouble for the health of countless people in the world. Smoking is the part of most of English people's lives; a lot of them are seen smoking in various public places such as pubs, bars, streets, parks and bus stations. Regardless of being aware that smoking damages their health, they have not been able to easily give up on smoking due to several circumstances, including physical and mental addiction to smoking, stress in life, and peer pressure at young ages. This practice had raised a serious concern for public health, safety, and welfare since various scientific studies have proved that nonsmokers who are involuntarily exposed to smoke (called secondhand smoking or SHS). WHO has said that people experience the same or more serious health problems as active smokers because of the emission of smoke to the air. Besides public health, safety and welfare concerns, smoking in public places also badly impacts the surrounding environments.

There is a long history of finding the detrimental effects of smoking on health in the UK. Though many shreds of evidence were published since the 1950s and onwards to show the negative impacts of smoking on health, the public, as well as many health professionals, ignored the fact. But the breakthrough came when Hills and Doll study was conducted on a large scale, to study the association of smoking and lung cancer. The large breakthrough came in the year 1962 when the Royal College of Physicians (RCP) published a study report on the association between lung cancer and smoking (1). The Royal College of Physicians in 1962 published the data of smokers- 70 per cent men and 43 per cent women in the UK. At the same time, the publication reviewed various epidemiological and social studies and pinned out that the cause of lung cancer, bronchitis and coronary disease was due to smoking (3).

Smoking is still the public health problem and is considered as one of the biggest avoidable causes of morbidity and mortality in the UK. The research paper brought to light the burden of smoking - related ill health in the UK and also illustrated that the number of deaths due to smoking in 2005 was 109,164 (19\% of all deaths, $27 \%$ deaths in men and $11 \%$ of deaths in women)(3). Similarly, one - third of deaths in the UK was due to smoking - related cancer and the risk probability of dying is double at the age before 65 if one smokes regularly (2). Moreover, the direct cost to the NHS was $£ 5.2$ billion in 2005-06. This was the huge loss of life and enormous allocation of fund for the treatment of people (3).

During the periods of the 70s to 80s, there was a massive discussion on the detrimental effects of smoking, and passive smoking was an emerging issue for health professionals. In the years of 70s, a campaign was initiated to impose voluntary and partial ban of smoking in public places, by putting up signs and logos of NO SMOKING. And one of the ruling parties, the Labor Party, introduced the ban of advertisement of cigarette on television to discourage people from attraction of smoking. The concerns regarding secondhand smoking came to the ground after various medical scientific researches and publications quantified and confirmed the health risk of passive smoking after exposure with it; which drew the public attention. The turning point for the government to introduce a ban of smoking at public and workplaces to protect the right of nonsmokers to enjoy fresh air, came after it was strongly backed by the recommendation given by SCOTH regarding SHS(4).

Despite the long-standing attempts of tobacco industries and various interest groups to discredit the scientific and medical research on SHS, in the name of loss of profit, personal choice and freedom to smoking, government of England passed the legislation of ban on smoking in enclosed public spaces and workplaces which took effect throughout the UK under the 2006 Health Act. The voluntary approach was tried, evaluated, and then replaced by legislation after not working

\subsection{Purpose of the study}

Government had the utmost urgency to address the huge numbers of lives lost and disabilities caused by smoking and protect future generations from being addicted to smoking. The major objective of this policy is to limit the preventable epidemic of smoking.

The specific objectives of this policy are:

Smoking is harmful not only to smokers but also to people around them; so, policy has stressed on reducing exposure to secondhand smoke to improve public health.

Protect employees, children and the public from harm and to enjoy smoke-free air by recognizing a person's individual right. 
Save thousands of lives by reducing overall smoking rates, as there are more deaths from smoking - related illnesses which increase the risk of cancers and premature death.

Educate the public about the advantages of smoke-free enclosed public places and workplaces creating favorable environment for people trying to quit smoking risk where the social pressure to smoke is decreased.

Smoking is the most important cause of premature death in developed countries like England. The relevance of policy was to eliminate one - third of the smoking - related cancer deaths in Britain and one - sixth of the deaths from other causes (4). Through this policy, the government also supports internationally recognized comprehensive tobacco control standard. England followed other nations of UK viz. Scotland, Wales and Northern Ireland to ban smoking in public premises and working places. Smoking is strictly prohibited in a car when children are present which reduces the health risk to them.

\section{Methods}

This policy is based on the Health Policy Triangle which considers the interaction of all four elements (Content, Context, Process and Actors) to structure policymaking. This policy also highlights the significant roles of all the sectors cumulatively for successful formulation and implementation of the policy(5).

For the purpose of analyzing policy, the data and necessary information were obtained from various published and unpublished written sources. Searches were article from databases like PubMed and the widely used search engine was Google Scholar with the phrase 'Smoking ban in the UK', 'Policy on Smoking Ban'. This also helped to find out the news published on paper at that time related to the smoking ban. In addition to these, policy document and reports released on a periodic basis of the government have also been extensively used during policy analysis.

The Kingdon model best fits this policy during agenda settings. For the formulation of legislation problem, political and policy stream must have proper alignment which is best described in this model (5). The policy was successfully established as public agenda as numbers of medical and scientific evidence had proved the association of SHS and smoking - related illness. This evidence shifts the public people attitude towards the judgement of the issue; this is the problem stream. As a result, the government of the UK realized the fact that protection from SHS could not be easily solved by only voluntarily banning and moved towards a smoking ban in public places. This shows the policy stream. Finally, due to wider civil society organization such as ASH to help to make the issue the public case for action and supportive Medias creating public climate conducive to action make the issue as a political agenda. Eventually, the Labour Party put this issue in its manifesto in 2005. This shows the government feeling of ownership of the issue. After their win, the government was able to pass the bill with the tremendous support of public people through the free vote of their representative in the parliament(6).

The implementation phase of the policy was based on the Top-down approach which means, that policy formulation and decisions for implementation was made at the top level and then implemented downwards to local authorities and administrative units(5).

\section{Results}

\subsection{Stakeholder Analysis}

In this section, we will discuss the following stakeholders involved in formulation and implementation of Smoke - free premises.

\subsubsection{Labour party}

The labour party was founded in 1900. It is formed by working-class people, trade unionists and socialists. It is the center - left political party which represents the voice of working-class people in the British Parliament. The era of the new labour party started after the regime of Tony Blair. In 1997, the labour party won with the majority. There were many positive changes in Britain. It brought many changes for the betterment of the country. In 2005 there was the election and the labour party although won for the third time, but the majority was reduced and had the lowest percentage of any majority government in British history. In 2005, after the frequent media coverage and support from the public towards the ban of smoking, finally, the labour party kept the issue in their election manifesto. It also allowed MPs free vote in parliament to vote on the smoking ban policy in public places $(7,8)$. 


\subsubsection{The Royal College of physicians (RCP)}

The Royal College of physicians (RCP) had been working on a ban of smoking for more than 10 years in the UK. They were physicians who had the power of technical authority and knowledge. Their initiatives had a great role in reducing smoking prevalence from 70\% of men in 1962 (the year the Royal College of Physicians published their groundbreaking study that concluded smoking was a cause of lung cancer) to $24 \%$ in 2005. Physicians were demanding more strict law and government intervention on policy formation. It recommended tougher laws on sale, advertisement and sponsorship by the tobacco industry. In 1983, for the first time danger of passive smoking was reported by RCP(10).

\subsection{Tobacco industry and hospitality trade}

Tobacco is considered as one of the most commonly used addictive substances in the world. Many persons and companies involved in its preparation, sale and distribution comprise as tobacco industries and hospitality trades(11). They are global industries run for the profit-making motives and run under government rules and regulation. They have a membership-based association like the Tobacco Manufacturers' Association (TMA), the British Beer and Pub Association (BBPA). Consumer spending on tobacco in the United Kingdom in 2005 was 15302 million in GBP(12)

Many public places like cinemas and transport had already banned smoking by late 1990s but many enclosed hospitality venues were behind the discussion of policy. Tobacco industry put tremendous effort and resources into preventing the policy from being passed. The tobacco industry has gone a long run to discredit the medical and scientific research on secondhand smoke. The campaign of tobacco industries was not limited at convincing to their own members to go against the smoking ban, but also built a strong alliance with hospitality trade for self-regulation; the fact behind this collision was the hospitality trade in the UK was large and widespread geographically. The industry with the support of the hospitality trade was making smoking as a leisure object and was not banned to smoke in most of the hospitality venues before 2006 (8). The industries funded various front organization and people led a group against legislation. For example, Smokers' pressure groups FOREST which supported a policy of separate spaces for smokers and non-smokers. And appealed to reject calls for a ban on smoking in all public places. FOREST tried to promote itself as a pro smoker rights group.

\subsection{Action on Smoking and Health (ASH)}

The Action on Smoking and Health (ASH) is a public health charity group established in 1971 by the Royal College of Physicians which represents academics and professionals from the fields of medicine, public health, public relations and politics. It advocates regarding the harm caused by tobacco and works to ban it. The objectives of the ASH are to promote and protect the physical and mental health of the community people and help them in reducing the tobacco intake and carry out, assist, promote and encourage research on cigarettes and other forms of cigarette. Department of Health, UK, British Heart Foundation and Cancer Research UK funded ASH to advocate, research and campaign on tobacco control. ASH provides the secretariat for a cross-party group of peers and MPs called All Party Parliament Group (APPG)(13, 14).

ASH in coalition with Royal College of Physicians, the British Medical Association started to lobby through campaign towards more comprehensive smoke-free legislation. The campaign worked with local authorities, employers and lawyers. It was successful to gain political support in both Houses of Parliament which resulted in fewer exceptions than the first version proposed by the government $(13,15)$

\subsection{Media}

Media played a vital role in change of any circumstances prevailing at that time. There is various version of media as paper, TV and electronic to disseminate the message between the public and concerned authority and vice-versa.

From the very beginning of the campaign, the proactive and reactive of media was highly effective during policy formulation. Different media were used for opinion polls and surveys about the ideas of the harmfulness of secondhand smoking at workplaces and enclosed areas(15).

On the other hands, media were used for effective means for the dissemination of scientific studies reports on the detrimental effect of SHS. In such a way seminal reports and views of expert got their place on the media. Quick but effective circulation of any political change regarding the issue was crucial at the time where media were widely deployed during the campaign in England. Pressure group ASH used media monitoring in March 2004 and February 2006 which was significant when the billed was passed smoke-free stories had already reached to an audience of 4.5 million people which was significant levels of coverage. (1) 
Table 1 Stakeholder Analysis

\begin{tabular}{|c|c|c|c|c|c|}
\hline \multicolumn{6}{|l|}{ Position Map } \\
\hline Stakeholder & Characteristics & Resources/Power & $\begin{array}{l}\text { Interest in the } \\
\text { issue }\end{array}$ & Position & $\begin{array}{l}\text { Impact of } \\
\text { issue/commitment }\end{array}$ \\
\hline $\begin{array}{l}\text { Government } \\
\text { (Labour Party) }\end{array}$ & $\begin{array}{l}\text { Center }- \text { left } \\
\text { political party in } \\
\text { UK }\end{array}$ & $\begin{array}{l}\text { Tangible: } \\
\text {-Finance } \\
\text {-Trade Unions } \\
\text { - Media } \\
\text { Intangible: } \\
\text { - Research } \\
\text { - Evidence Public } \\
\text { - } \\
\text { consultation } \\
\text { - free vote }\end{array}$ & $\begin{array}{l}\text { High } \\
\text {-To pass the } \\
\text { legislation as } \\
\text { the support } \\
\text { from general } \\
\text { public was } \\
\text { immensely } \\
\text { high and was } \\
\text { even in their } \\
\text { manifesto } \\
\text { during election }\end{array}$ & Supportive & $\begin{array}{l}\text { High } \\
-\quad \text { Smoke free } \\
\text { legislation } \\
\text { into action }\end{array}$ \\
\hline $\begin{array}{l}\text { Royal college } \\
\text { of physicians }\end{array}$ & $\begin{array}{l}\text {-Physicians daily } \\
\text { in contact with } \\
\text { the public health. } \\
\text {-Non- } \\
\text { governmental } \\
\text { organization. } \\
\text { - working for } \\
\text { better practice in } \\
\text { medicine. }\end{array}$ & $\begin{array}{l}\text { Tangible: } \\
\text {-High number of } \\
\text { members. } \\
\text {-Good economic } \\
\text { resources } \\
\text { Intangible: } \\
\text { - Knowledge } \\
\text {-Power because of } \\
\text { authority }\end{array}$ & $\begin{array}{l}\text { High interest, } \\
\text { lot of } \\
\text { knowledge on } \\
\text { the } \\
\text { devastating } \\
\text { impact } \\
\text { smoking has } \\
\text { on the public } \\
\text { health. }\end{array}$ & Supportive & $\begin{array}{ll}\text { High } & \\
\text { Long } & \text { term } \\
\text { commitment. } & \\
\text { Accepted } & \text { and } \\
\text { recognized. } & \end{array}$ \\
\hline $\begin{array}{l}\text { Tobacco } \\
\text { industries and } \\
\text { Hospitalities }\end{array}$ & $\begin{array}{l}\text { Profit making } \\
\text { firms run under } \\
\text { the UK } \\
\text { government law. }\end{array}$ & $\begin{array}{l}\text { Tangible: } \\
\text {-Finance from } \\
\text { members } \\
\text {-Trade Association } \\
\text { Intangible: } \\
\text {-Knowledge }\end{array}$ & $\begin{array}{l}\text { High } \\
\text {-to prevent } \\
\text { policy being } \\
\text { passed due to } \\
\text { fear of } \\
\text { economic loss. }\end{array}$ & Unsupportive & $\begin{array}{l}\text { Low } \\
\text {-Failed to stop the } \\
\text { policy being passed }\end{array}$ \\
\hline $\begin{array}{l}\text { Action on } \\
\text { Smoking and } \\
\text { Health }(\mathrm{ASH})\end{array}$ & $\begin{array}{l}\text { The charity } \\
\text { group consisted } \\
\text { of doctors, } \\
\text { specialists of } \\
\text { public health, } \\
\text { public relations } \\
\text { and politics } \\
\text { across the UK }\end{array}$ & $\begin{array}{l}\text { Tangible: Finances } \\
\text { Intangible: Access } \\
\text { to media, } \\
\text { expertise and } \\
\text { collaboration with } \\
\text { other networks }\end{array}$ & High interest & $\begin{array}{l}\text { Highly } \\
\text { supportive } \\
\text { (unsupportive } \\
\text { towards the } \\
\text { exceptions) }\end{array}$ & $\begin{array}{l}\text { Policy accepted and } \\
\text { approved }\end{array}$ \\
\hline Media & $\begin{array}{l}\text { All types of } \\
\text { media }\end{array}$ & $\begin{array}{l}\text { Research and } \\
\text { evidence-based } \\
\text { news } \\
\text { dissemination }\end{array}$ & $\begin{array}{l}\text { Economic and } \\
\text { political } \\
\text { interest, public } \\
\text { support, } \\
\text { concerned } \\
\text { actors' interest }\end{array}$ & $\begin{array}{l}\text { Highly } \\
\text { supportive }\end{array}$ & $\begin{array}{l}\text { Highly successful in } \\
\text { formulation of } \\
\text { policy }\end{array}$ \\
\hline
\end{tabular}




\subsection{Policy Process}

\subsubsection{Policy Identification}

In this section, Agenda Setting for smoke - free premises, act is done using 'Kindon's Model' to analyze how the smoking in public places became a problem, which factors influenced it and the stakeholders involved in the process and how the English people supported the act(5) .

The first part of the model is problem stream which answer the questions like why the act was necessary for the people of UK and what was done before this act was raised as an agenda by government or stakeholders(5).

In the year 1950 the relationship between smoking and lung cancer was established by Richard Doll and Austin Radford Hill(8). Cardiovascular disease, Chronic Obstructive Pulmonary Disease (COPD), lung cancer and a range of peptic ulcer and various other health problems was rising mainly due to high prevalence of smoking in the population(3). Doll and Hill pointed out that mortality from lung cancer can be reduced by reducing the smokers and thus can decrease the economic burden of the disease in the country (8). However, in late nineties also, passive smoking was one of the burning public health issues in UK. All age groups even the unborn child was at risk due to Environmental Tobacco Smoke (ETS) (16).

In $2002,30 \%$ of working adults were smokers and $42 \%$ of the population was exposed to passive smoking in their home. The mortality related to passive smoking was 3343 which was more than two people dying due to passive smoke in working days (17). In 2003, around 11,000 adults in home and 617 people in workplace died in UK as a result of exposure to SHS(18). It was estimated that $66.6 \%$ of throat cancer was caused due to smoking while $2 / 3^{\text {rd }}$ of it could be reduce by stopping use of cigarettes (19). $12 \%$ of Disability Assessment Life Years (DALY) was directly responsible with smoking (15.4\% in men and 8.5\% in women) and direct cost to the NHS was $£ 502$ billion in 2005-6(3). 2.2 million people smoked in workplace where smoking was allowed at any place while 10.7 million people smoked in places where smoking was allowed at only some places(13). When the people falls ill from smoking then the country loses it productivity and tax revenue at the time they are not working thus increasing the burden on the health care(20).

If this issue of passive smoking was not intervened, then future generation would be badly affected, and the economy of the country would degrade. So, to protect public from passive smoking, the white paper "Smoking Kills" was proposed in 1998. The paper had option of voluntary approach and focused on awareness campaign and nicotine replacement therapy for reducing smoking but excluded hospitality trade groups. Many places restricted or banned smoking in workplaces, shops, public transport and other public environment. The tax was increased to 5\%(8, 21). Tobacco Advertising and Promotion Act 2002 came into effect which end tobacco advertising in UK(13). Regardless of all these, the annual report for 2002 from the government's Chief Medical Officer (CMO) Dr. Liam Donaldson showed mandatory approach was needed as voluntary approach was not reducing health risk in secondhand smoker $(8,15,21)$.

The second part of the Kindon's Model is the policy stream where the proposed act was discussed between various stakeholders and on the effective solution towards the ban on smoking(5). Majority of the actors were in the favor of the ban of smoking in the public places.

Ireland had made it illegal to smoke in public places since 2004 and Scotland and Wales were also in that process, but England was still unsure in regard to the strictness(21). With the rising inequalities in the country and issues of smoking causing serious public health issue, the government published white paper, Choosing Health : Making Healthy Choices Easier, in November $2004(8,22)$. Environment, social networks and income affect the health of the people so choosing health ban smoking in enclosed public places and workplaces(23). The evidence suggested that risks of heart disease in secondhand smoker was double than what was known before. The people wanted to stop smoking but they ended up smoking in the name of being social, so they needed government to take step. Making the individual choice was one thing but coming home feeling as an ash tray was completely different than what they have wanted(21, 24) . People wanted the government to be ensured that its citizens to be healthier(24).

Following the public consultation white paper was published with the aim of reducing inequalities and cause of ill health due to smoking (24). It emphasized on helping the smokers to quit and keeping warning sign on tobacco products effectively (25). On the other hand, through the opinion polls and survey media was constantly gathering the views on ban on smoking as well as it was giving the evidence-based message that secondhand smoking was the reason of many avoidable death and only solution towards it was strong legislation(15). Tactically, seeing wide acceptance from public towards the ban on smoking the Labour Party kept it in their manifesto for their upcoming election on 2005 (8). 
The third aspect of the Kingdon Model is Politics stream and it depends on policy makers and the politicians of various party as well as the actors in the policy making(5).

Labour government was in favor of the smoke free workplace legislation. Scientific Committee on Tobacco and Health appointed by government concluded that passive smoking is a cause of lung disease and coronary heart disease(8). In 1998, it had proposed an approved code of practice (ACOP) to the health and Safety Work Act called "Smoking Kills" and was officially launched in 1999. The year after 1999, saw an increase support towards more restrictive ban in public places. Although the report stated that there was less decline in smoking, but it showed that nonsmokers were against second hand smoke and demanded strong government interventions(26). On the other hand, there were research group and companies been sponsored by Philip Morris and was called Project Whitecoat whose intention was to prove medical and scientific experts wrong who reported that SHS is harmful and was cause of ill health(15) .

More comprehensive act was proposed again by Labour party in 2004 entitled Choosing Health: Making Healthy Choices Easier(15). In October 2005, legislation came as a part of the health improvement and protection bill and came into effect only in 2007(26). However, in the beginning, health minister, from the labor party itself, was not convinced that the smoke free premises was the solution to protect people from second hand smoke(8) and also the department of Health Economist was of the view that ban would not have any immediate benefits on passive smoker instead it will discourage the young from starting(8).

\subsubsection{Policy Formulation}

In past years, the Government focused on treatment rather than focusing on helping patient to find the root cause of illness to minimize it. Poor peoples were less healthy than rich. The inequalities were rising within the country. So, with the aim of making all the citizens of nation healthy, the white paper entitled Choosing Health: Making Healthy Choices Easier, was proposed(27). It set the target that by 2008 all enclosed public places and workplace would be smoke free with some exceptions (24). The restaurants, pubs and bar which prepare and serve food would go smoke free and strict regulation would be enforced on advertising related to tobacco(25). The choosing health was prepared by HM government and Department of Health with the support from NHS. The purpose of the act was, to make it easier for people to choose healthy lives, healthy children and young people, community approach for healthy individual, healthy way of living, support NHS and healthy workplace.

\subsection{Situational Factors}

London Health Commission started the consultation called "The Big Smoke Debate" in October 2003, in which 125,000 public from seven regions registered their opinions on website or via freephone. $79 \%$ of the respondent were in favor of the law to make workplaces smoke free. While in November 2003, Labor party launched the public consultation "The Big Conversation" where 85\% of the respondent was of the view that councils had the power to ban smoking in public and workplace(15).

Outdoor smoking ban was a topic of debate in the UK but the issue on indoor ban was on peak, so the government proposed the act in accordance to it. However, with an exception. Within the government departments, there was a mixed reaction on ban on smoking in public places which led to little progress by 2003. The then Health ministry, John Reid, who himself was the heavy smoker and had quit before joining the post, was skeptical about the ban and even said that banning smoking in public places will increase smoking in homes however, the evidence and research put forward by Royal College of Physician proved him wrong(15). John Reid even moved further in his view and said publicly that many people take cigarettes to escape their stress and pressure. His saying was heavily criticized by publics. The large group of people against his saying proved that they are in support of it(8). On the other hand, Patricia Hewitt who succeeded John Reid as health minister was in the favor of complete ban but had to back down due to opposition from her ministerial colleagues(26).

After publishing the white paper in 2004 there was the consultation period till 2005 and written evidence was sought from the stakeholders. Some of the feedbacks were (28)

"We welcome the proposal for legislation to end smoking in the great majority of workplaces and enclosed public places.... However, we have serious concerns about the timescale for the proposed legislation and particularly about the proposed exemption from pubs that do not serve prepared food and for private membership clubs." 


\subsubsection{Memorandum from Action on Smoking and Health (ASH) (WP07) (p.37)}

The promises on spending on health promotion are without substance in terms of budget or stated aims. High profile sustained and varied campaigns are effective but need a substantial budget. We believe low-key activity will not achieve much.

\subsubsection{Memorandum by the Royal College of Physicians (WP 24) (p. 82)}

At the end, government optioned to allow a free vote in parliament. In February 2006, the House of commons voted and by the majority of 200, ban on smoking was introduced in England and Wales from 1 July 2007. In government offices and all NHS ban was introduced in January $2007(15,26)$. The National force task was responsible to regulate the smoke free environment(23).

\subsection{Structural Factors}

Media was actively working to aware people about the harm related to SHS and the organization in favor of ban took advantage of power of media. The media coverage during the formation of legislation and passing of legislation was monitored by ASH(15).

In 2004, a research was conducted in Great Britain by MORI (Market Opinion Research International) commissioned by ASH, in which data was collected from different location. The total of 4000 took part in analysis which concluded that four out of five supported bans in workplace.

Health professionals were not satisfied by the restriction that was put forward in white paper. They wanted the comprehensive ban and cancer research also stated that partial ban would increase the health inequalities. There was the possibility that the pubs and restaurants shift from serving food to selling cigarettes(29).

ASH and Chartered Institute of Environment Health (CIEH) produce a guideline called Achieving Smoke Freedom Toolkit. This toolkit was to inform the local authorities and Primary Care Trusts (PCT) the importance of smoke-free area in workplace and enclosed public places. The "Tobacco Smoke Pollution: The Hard Facts" document was produced to explain the importance of ban and gained positive media response(13). The duos also supported the local level for developing movement against smoke - free environments(15).

The tobacco industry was against the banning of smoking in closed premises. It used hospitality trade as a focal point to the argument that voluntary approach was sufficient to respond SHS and hospitality trade economy would be affected by ban, in response to it, the ASH collaborated with major trade union law firms and increased the pressure to hospitality trade threatening that it had failed to protect the employees from second hand smoke and issued the warning letter according to "date of guilty knowledge" under the Health and Safety Work Act employee must be aware of the consequences of the second hand smoke. This letter received the media coverage. Subsequently many supported smokefree legislations $(13,15)$. Further, the research conducted in New York and Ireland justified that economy of the hospital trade would not be affected however, some structural adjustment would be necessary(15).

Tobacco industry and smokers were of the view that if smoke was the issue for the nonsmokers than well ventilated room could be a remedy to remove smoke from bars and pubs, and there was no need of the ban. However, researcher and the medical profession claimed that ventilation can't be the remedy from public getting lung cancer from SHS (26). In May 2004, head of British Hospitality Association (BHA) said publicly that voluntary approach was the story of past, in present context the smoking ban is necessary(15).

Tobacco funded front organization (FOREST) rejected ban on smoking that the rights of smokers were hampered but it backed out when all polls and public consultation proved that even smokers were in favor of ban of smoking in workplace(15).

\subsection{Cultural Factors}

Smoking was the part of the lifestyle in England and people were arguing that they were capable enough to decide right and wrong regarding their health. So, the smokers were of the view that it was not the state's role to restrict them from smoking, but they were counter attacked by the point that they should not harm other rights to breathe fresh air while exercising their right(26). The legislation however, was not to stop the people from smoking and make smoking illegal but was focused on protecting the health of people from SHS(8). 


\subsection{International Factors}

In 2003, the New York city and some of the town and cities of California banned smoking in public premises and some even in beaches and public parks. Ireland was the first European country to ban smoking in workplace in 2004 . Italy and Norway also enforced a total ban on smoking in pubs and bar(26). UK also formally ratified the WHO FCTC on Dec 2004. It came into effect on 28th Feb 2005. It was on strict Tobacco control focusing on measures to protect people from SHS, leveling tobacco products with health warning, ban on advertisement and sponsorship, combat smuggling and increase tobacco taxes (30). The biggest thing in the international arena is that the UK was first among the FCTC parties to introduce comprehensive smoke free legislation.

\subsubsection{Policy Implementation}

The tireless effort of more than a decade long campaign of concerned authorities, health campaigners and the public voice for the implementation of smoke free law in England came to be true on 14th February 2006. The vote was massive majority in favor of legislation in the house of Commons which was passed by 384 to 184 for comprehensive smoke free legislation. The legislation came into action on 1 July 2007 very successfully to make all enclosed public places and workplaces smoke free(31). The Regulatory Impact assessment of the government had expected that more than 6 lakhs people will give up smoking after the legislation (15).

The best approach applied for the implementation of this policy seems 'Top Down'. There was rigorous public debate with consultation of medical and scientific evidence and publication for identification of the problem. The agenda was well established by research and the carryover of it for public agenda was the effort of political party, organization like RCP, ASH, Media regardless the tremendous effort done by tobacco industries and hospitality to stop it. The policy was passed by the central government of UK and forwarded to local authorities and subordinated administrative units for implementation with clear objectives, its goal and implementation outcomes.

The UK is the first country to implement the compliance of the FCTC and EU council recommendation which was to introduce measures to protect public from exposure to secondhand smoking in indoor workplaces and public areas. After new law enforced in England, the Department of Health's Policy Research Program was assigned for evaluation of the effect after implementation of the law. The scope of the studies was to examine the health of bar worker and air quality; key health outcomes and prevalence of smoking; impact on attitudes, and to explore the hospitality sector. The key findings of studies were disseminated in the report to show significant of impact in public(32).

Local authorities were main responsible for enforcing policy at lower level of administrative units. The Local government Analysis and Research organization (LGAR) was designated for the purpose of date collection from local authorities to explore compliance of smoke free compliance. The Department of Health has commissioned the Local Government Analysis and Research organization (LGAR) to collect data from local authorities on their smoke free compliance inspections. Reports disseminated after inspection from local bodies have confirmed high levels of compliance with smoke free legislation. And hearty acceptance of law by public and business and adoption quickly. The statistical data About 87 per cent of all premises and vehicles were displaying the correct no-smoking signage and 98 per cent of above-mentioned areas were smoke free as specified of the law was really overwhelming impact shown (31).

Employees of bar and pub houses were badly affected by SHS which accounted the reduction of $10 \%$ from $80 \%$ after introduction of comprehensive smoke free legislation. Similarly, the data showed only there were $2.4 \%$ reduction in hospital admission in a year for heart attack and almost 7000 fewer admission due to childhood asthma (18).

Baseless argument was given by tobacco factories and their alliance for the policy would be unsuccessful. They also often said that the law would not work and not be supported by public. In contrast to this 53 per cent people support the law and more than that an addition 300000 smokers were inspired to make quit of their smoking behaviors as the policy was implemented $(8,18)$. Nearly 7,000 pubs were closed during the period of 2007 to 2015 . Though the reason behind the shutdown was difficult to analyze due to only ban or other circumstances factors; the landscape of pub was dramatically changed since enforcement of policy becoming more family friendly and many pubs had to change their traditional way of business to run further (8)

In particular, the comprehensive ban on smoking of the Ireland was the best-case study of effective legislation for England. Similarly, Scotland, Wales and Northern Ireland had already similar policy on smoking case. The weight of medical and scientific evidence base for action, campaign over years of public health community, leadership from civil servants and ministers, and from wider civil society is worthy to count for legislation implementation. Health Secretary Patricia Hewitt who voted for a total ban for England, told the BBC: "I'm absolutely delighted. This is really a historic day for public health. "She added: "This is going to save thousands of people's lives"(33). 


\section{Conclusion}

There has been much to celebrate after banning of smoking not only the health indicators of health status but also to their attitude towards smoking has been widely changed Smoking ban policies have shown effective public health interventions for the prevention of cardiovascular, cerebrovascular, and respiratory mortality and preserve the health of children.

Cigarette smoking is still a leading preventable cause of death and is a serious public health issue. It affects every part of the organ and further reduces the life expectancy of the people. The children whose lungs were developing had the devastating detrimental effect of second hand smoke and were more prone to respiratory tract infection than adults.(34). In order to protect the future generations as well as the economy of the country the policy played a vital role in England. The ban was urgent need in many public places as the report from CMO from the government concluded that due to voluntary approach was less effective measure in controlling smoking in population(8).With the aim of reducing inequalities and cause of ill health due to smoking Health Act 2006 was introduced on 1st July 2007. Before its release in 2004, white paper, Choosing Health: Making Healthy Choices Easier was published. The white paper gained large support from the local people, civil organizations and political party(8).

Toby Green on the mark of 10 years of ban on public place smoking said "ban was the biggest public health intervention we've seen in the last 15 years" (34). The act has made significant contribution in the protection of health of nation which is proved by the drop of hospital admission for heart attacks. While observing the historical records of past last decade, the burden of this hospital admission due to disease related to smoking has been decreasing (16). Smoking ban on closed premises had improved the health of the individual and is able to modify/change the attitudes and behaviors of the people (22).

Many Stakeholders had their tireless effort and fight for this story to be successful despite the hard effort of tobacco and hospitality trade which were totally against it. It is fact that all policy requires political commitment to be formation and execution. It is open secret the politics of tobacco industries are politically powerful than those who advocate to preserve the health of children and nonsmokers from tobacco(35). And media was one of the most contributing to this campaign making people aware and sensitive to this issue. Finally, Labor party took strong position on it and finally made successful. It was made political agenda widely contributed by joint effort of stakeholder, medias, and civil societies. And the representative of people, MPs casted vote at parliament and the policy was passed with majority votes. This; the consistent support of public people and improving health indicators now has moved the government pledge to end smoking in England completely by 2030. The smoking ban policy has made UK foremost nation leading the EU league table for tobacco control.

\section{Compliance with ethical standards}

\section{Acknowledgments}

All authors provided critical input and revisions.

\section{Disclosure of conflict of interest}

All authors declare no conflict of interest. No funding was received

\section{References}

[1] Royal College Of Physicians: Report On Smoking. The British Medical Journal. 1962; 1(5279):703-5.

[2] London Assembly. Smoking in Public Places Investigation Committee Scrutiny of smoking in Public Places in London. London; 2002.

[3] Allender S, Balakrishnan R, Scarborough P, Webster P, Rayner M. The burden of smoking-related ill health in the UK. Tobacco control. 2009; 18(4):262-7.

[4] Poswillo DE. Report of the scientific committee on tobacco and health: Stationery Office; 1998.

[5] Buse K, Mays N, Walt G. Making health policy: McGraw-Hill Education (UK); 2012.

[6] Cairney P. The transformation of UK tobacco control. Great Policy Successes. 2019:84. 
[7] Party TL. Labour's Legacy 2019 [cited 2019 Nov 7th]. Available from: https://labour.org.uk/about/labourslegacy/.

[8] Instituteforgovernment.org.uk [cited $2019 \quad 20$ th $\quad$ October]. $\quad$ Available from:https://www.instituteforgovernment.org.uk/sites/default/files/smoking in public places.pdf.

[9] Royal College of Physicians. History of the RCP [cited 2019 7th Nov]. Available from: https://www.rcplondon.ac.uk/about-us/who-we-are/history-rcp.

[10] London RCoPo. Smoking and Health: Summary of a Report of the Royal College of Physicians on Smoking in Relation to Cancer of the Lung and Other Diseases: Pitman Medical Publishing Company Limited; 1962.

[11] Wikipedia. Tobacco Industry [cited 2019 7th Nov]. Available from: https://en.wikipedia.org/wiki/Tobacco industry.

[12] Consumer spending on tobacco in the United Kingdom from 2005 to 2018 (in million GBP)* [Internet]. [cited 7th Nov, 2019].

[13] ASH.Action on smoking and health. ASH account 2019 [cited 2019 24th Oct]. Available from: https://ash.org.uk/about/ash-accounts/.

[14] ash. action on smoking and health, 2019 [cited 2019 24th Oct]. Available from: https://ash.org.uk/about/.

[15] Arnott D, Dockrell M, Sandford A, Willmore I. Comprehensive smoke-free legislation in England: how advocacy won the day. Tob Control. 2007; 16(6):423-8.

[16] Edwards R, Coleman T. Going smoke-free: the medical case for clean air in the home, at work and in public places. Clin Med (Lond). 2005; 5(6):548-50.

[17] Jamrozik K. Estimate of deaths attributable to passive smoking among UK adults: database analysis. BMJ. 2005; 330(7495):812.

[18] ASH (Action on Smoking and Health). 10 years of smokefree legisltaion : the facts. 2017 July 2017.

[19] Organization WH. The world health report 2002: reducing risks, promoting healthy life: World Health Organization; 2002.

[20] Kirk A. When it comes to smokers' burden on the NHS, they may well contribute more in tax than they take. The Telegraph. 2017; Sect. News.

[21] Patrick Wintour cpc. Labor to ban public smoking. The Guardian. 2004 Wed 30 Jun 2004.

[22] Post - Legislative Assessment of Health Act 2006. In: Health Do, editor.

[23] The NHS Confederation. <The Public Health white paper.pdf>. 2004.

[24] Health Do. Choosing Health: Making healthy choices easier 2004. p. 207.

[25] News B. At a glance: Public Health White Paper. BBC News. 200416 November 2004; Sect. News.

[26] Smoking Ban [cited 2019 20th October]. Available from: https://www.politics.co.uk/reference/smoking-ban

[27] HM Governemnt DoH, NHS,. Choosing Health A booklet about plans for improving people's health In: Health Do, editor.

[28] Committee HoCH. The Government's Public Health White Paper (Cm 6374) Written Evidence.

[29] agencies Sa. Ministers urged to rethink smoking ban plan. The Guardian. 2005 5th Sep 2005.

[30] UK ratifies global tobacco treaty: now is the time for a long term strategy to cut tobacco use [press release]. 16th Dec 20042004.

[31] Department of Health. Smokefree England- one year on. DH L; 2008.

[32] Bauld L. The impact of smokefree legislation in England: Evidence review. 2011.

[33] BBC News. Smoke ban bill details released. BBC News. 200527 October 2005.

[34] Heart Matter. How has the smoking ban changed our health? Heart Matter.

[35] Organization WH, Control RfIT. WHO report on the global tobacco epidemic, 2008: the MPOWER package: World Health Organization; 2008. 